\title{
Detection of bacterial sulfatase activity through liquid- and solid-phase colony-based assays
}

Hey Young Yoon ${ }^{1 \dagger}$, Hyung Jun $\mathrm{Kim}^{2 \dagger}$, Soojin Jang ${ }^{2}$ and Jong-In Hong ${ }^{1 *}$

\begin{abstract}
Bacterial arylsulfatases are crucial to biosynthesis in many microorganisms, as bacteria often utilize aryl sulfates as a source of sulfur. The bacterial sulfatases are associated with pathogenesis and are applied in many areas such as industry and agriculture. We developed an activity-based probe $\mathbf{1}$ for detection of bacterial sulfatase activity through liquid- and solid-phase colony-based assays. Probe $\mathbf{1}$ is hydrolyzed by sulfatase to generate fluorescent $N$-methyl isoindole, which is polymerized to form colored precipitates. These fluorescent and colorimetric properties of probe $\mathbf{1}$ induced upon treatment of sulfatases were successfully utilized for liquid-phase sulfatase activity assays for colonies and lysates of Klebsiella aerogenes, Mycobacterium avium and Mycobacterium smegmatis. In addition, probe $\mathbf{1}$ allowed solid-phase colony-based assays of $K$. aerogenes through the formation of insoluble colored precipitates, thus enabling accurate staining of target colonies under heterogeneous conditions.
\end{abstract}

Keywords: Bacterial sulfatase, Activity-based probe, N-methyl isoindole, Colony-based assay, Liquid-phase assay, Solid-phase assay

\section{Introduction}

Sulfur is a chemical element essential to all organisms, as it is required for the biosynthesis of cysteine and methionine; it is also involved in many redox reactions that take place in biological systems (Kertesz 2000). Microorganisms are capable of acquiring sulfur for biosynthesis by assimilating inorganic sulfates or organosulfur compounds, such as sulfonates and sulfate esters (Kertesz 2000; Stipanuk 1986). Bacterial arylsulfatases catalyze the hydrolysis of aromatic sulfate esters and participate in the metabolic pathways through which sulfur is procured by organosulfur compounds. Considering the ability to hydrolyze organosulfur compounds, bacterial arylsulfatases would be useful for many areas such as industry and agriculture (Stressler et al. 2016). In practice, bacterial arylsulfatases are applied in the desulfation of agar (Kim et al. 2004; Lim et al. 2004; Wang et al.

\footnotetext{
*Correspondence: jihong@snu.ac.kr

${ }^{\dagger}$ Hey Young Yoon and Hyung Jun Kim contributed equally to this work 1 Department of Chemistry, College of Natural Sciences, Seoul National University, Seoul 08826, Republic of Korea

Full list of author information is available at the end of the article
}

2015). Their activities are strongly influenced by bacterial growth environmental conditions and thus their measurements can be used for soil quality assessment (GarciaSanchez et al. 2016; Klose et al. 1999). In addition, it was suggested that sulfatase activity is related with the degradation of endosulfan, an extensively used insecticide (Kalyani et al. 2009; Narkhede et al. 2015). Recently, it was reported that sulfatases are potentially implicated in bacterial pathogenesis (Hickey et al. 2015). Furthermore, bacterial sulfatases might be involved in decomposition of sulfated mucins (Murty et al. 1992) and reconstruction of extracellular structures by desulfation of glycosaminoglycans (Mougous et al. 2002) for bacterial infection. However, despite of the various usages and the importance of sulfatase activity, only a few bacterial sulfatases were characterized.

Sulfatases contain the conserved Cys/Ser-X-Pro-XArg motif in their active sites. The first residue of the motif, which can be either cysteine or serine, is posttranslationally modified to form $\mathrm{C}_{\alpha}$-formylglycine (FGly), a unique amino acid that is the key catalytic residue for sulfate ester cleavage (Hanson et al. 2004; 
Knaust et al. 1998). In eukaryotes, the first residue of the motif is cysteine; inability to post-translationally modify this residue to form FGly in humans results in a rare lysosomal storage disease called multiple sulfatase deficiency (MSD) (Dierks et al. 2003; Diez-Roux and Ballabio 2005; Hanson et al. 2004). In prokaryotes, the first residue of the active site motif, i.e., the FGly progenitor, can be either cysteine or serine (Dierks et al. 1998; Marquordt et al. 2003; Miech et al. 1998). Sulfatases are believed to have either different FGly formation pathways or a common pathway with different modulating cofactors causing different localizations (Kertesz 2000). These reports indicate that post-translational modifications of sulfatases can regulate their activity, localization and/or stability, and all expressed sulfatases may not be capable of hydrolyzing sulfate esters (Hanson et al. 2004; Soufi et al. 2015). Thus, it is necessary to develop diverse assay methods for detecting sulfatase activity.

Determination of microorganisms expressing arylsulfatase requires a simple and easy assay method. Many methods for detection of arylsulfatase activity used bacteria cell lysates which were prepared through time-consuming and complicated processes. Colony-based assays are simple and thus can reduce sample preparation time. In addition, they also allow functional information to be acquired in an organism's physiological environment (An and Tolliday 2010). Solid-phase assays are proper ways to screen and isolate the potential bacterial strains that express arylsulfatases. Solid-phase assays that exhibit sharp and clear image changes according to sulfatase activity are particularly useful in directly detecting individual colonies of interest (Baud et al. 2015; Green et al. 2014; Weiss et al. 2014) and they could offer easy methods for industrial applications (Bric et al. 1991; Kasana et al. 2008). Therefore, a colony-based solid-phase assay method would be most appropriate one to study bacterial arylsulfatases.
Activity-based probes, based on detecting specific enzymatic activity in a cellular context, are powerful tools for enzyme activity assays (Heal et al. 2011). Previously reported activity-based probes for sulfatase activity assays contained luminophores and sulfate esters, with sulfatase activity inducing an optical response (Beatty et al. 2013; Park et al. 2012; Rush et al. 2010; Smith et al. 2014). Although those probes were characterized by fast response times and low detection limits, they were deployed in purified enzyme solutions or bacterial lysates.

We previously reported an activity-based probe $\mathbf{1}$ (Scheme 1), which enables detection of sulfatase activity in purified enzyme solutions through fluorescence enhancement (Yoon and Hong 2017). Probe 1 consists of sulfate ester as a substrate and benzaldehyde as a responsive unit, which are linked with a self-immolative moiety. The cleavage of the sulfate ester in probe 1 by sulfatase is followed by intramolecular cyclization, resulting in the formation of $\mathrm{N}$-methyl isoindole which emits fluorescence at $415 \mathrm{~nm}$. However, $N$-methyl isoindole is unstable and easily undergoes autooxidation and polymerization (Bonnett et al. 1973; Kochi and Singleton 1968; Rettig and Wirz 1976). The polymerization of $N$-methyl isoindole would trigger the formation of colored precipitates when a higher concentration of probe $\mathbf{1}$ was incubated with sulfatase for a longer period of time. These properties of probe $\mathbf{1}$ enabled us to detect sulfatase activity through liquid- and solid-phase colony-based assays (Scheme 1).

\section{Materials and methods}

\section{Cultures and growth conditions}

Klebsiella aerogenes was obtained from Hideko Urushihara at University of Tsukuba. Mycobacterium avium 104, and Mycobacterium smegmatis mc2-155 (ATCC $700084^{\mathrm{TM}}$ ) were obtained from Yonsei University. Staphylococcus aureus (ATCC $700698^{\mathrm{TM}}$ ) was purchased from

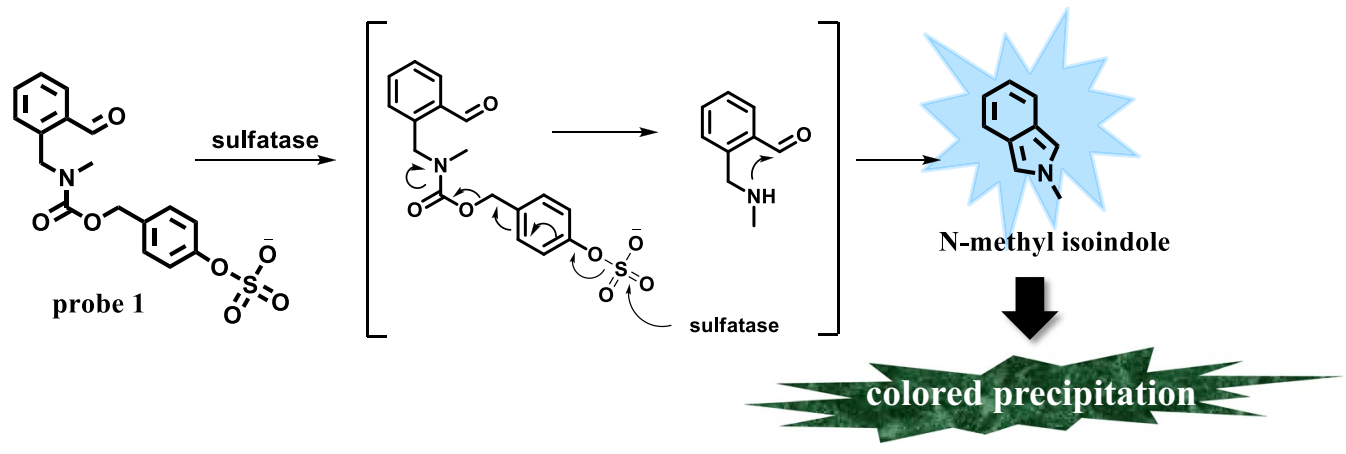

Scheme 1 Strategy of probe $\mathbf{1}$ for sulfatase activity detection 
American Type Culture Collection (ATCC). For the growth of $K$. aerogenes and $S$. aureus, Nutrient broth (NB) (BD Difco) was prepared according to the manufacturer's instruction, and the media was supplemented with $1.5 \%(\mathrm{w} / \mathrm{v})$ agar to make growth plates. For the growth of M. avium and M. smegmatis, 7H9 (BD Difco) media was prepared according to the manufacturer's instruction and supplemented with $0.5 \%(\mathrm{w} / \mathrm{v}) \mathrm{BSA}, 0.08 \%(\mathrm{w} / \mathrm{v}) \mathrm{NaCl}$, $0.2 \%(\mathrm{w} / \mathrm{v})$ dextrose, $0.1 \%(\mathrm{v} / \mathrm{v})$ tween 80 , and $2 \%(\mathrm{v} / \mathrm{v})$ glycerol to make the complete media. Also, 7H11 (BD Difco) growth plate was prepared according to the manufacturer's instruction, and supplemented with $0.5 \%(\mathrm{v} / \mathrm{v})$ glycerol, $0.05 \%(\mathrm{v} / \mathrm{v})$ tween $80,10 \%(\mathrm{v} / \mathrm{v})$ OADC solution. The bacteria were grown at $37{ }^{\circ} \mathrm{C}$, and the growth was monitored by the optical density at $600 \mathrm{~nm}$.

\section{Enzymatic assays of purified sulfatase with probe 1}

Probe 1 was synthesized according to modified literature procedures (Yoon and Hong 2017).

Biochemical activity assays with Helix Pomatia sulfatase (Sigma, S9226) and Aerobacter aerogenes sulfatase (Sigma, S1629) were carried out in 96-well plates with the total volume of each plate being $250 \mu \mathrm{l}$ at $37^{\circ} \mathrm{C}$ and $\mathrm{pH}$ 7.4. $1 \mathrm{mM}$ probe 1 and various amounts of sulfatase in $50 \mathrm{mM}$ Tris buffer were used.

The detailed procedures were described in the supplementary information.

\section{Sulfatase activity assays of microorganisms with probe 1 in liquid-phase}

For fluorescence reading, $250 \mu \mathrm{l}$ of bacteria and isolated bacterial lysates in Tris buffer $(50 \mathrm{mM}, \mathrm{pH} 7.4)$ were prepared in 96-well black microplates (Greiner). $2.5 \mu \mathrm{l}$ of probe $1(1 \mathrm{mM})$ was added to test wells, and the same volume of DMSO $(1 \mathrm{mM})$ was added to control wells. The fluorescence intensity $\left(\lambda_{\mathrm{ex}}=327 \mathrm{~nm}, \lambda_{\mathrm{em}}=415 \mathrm{~nm}\right)$ was measured at $37{ }^{\circ} \mathrm{C}$ in a time-dependent manner by the Victor3 multilabel plate reader (Perkin-Elmer) (0-240 min). For precipitation observations, $1 \mathrm{mM}$ probe 1 with bacteria or bacterial lysates in Tris buffer $(50 \mathrm{mM}$ $\mathrm{pH}$ 7.4) were prepared in the 96-well white plate (Falcon) and incubated at $37^{\circ} \mathrm{C}$ for $24 \mathrm{~h}$.

\section{Solid-phase colony-based assays}

We carried out the solid-phase assay with probe $\mathbf{1}$ following the published procedures (Baud et al. 2015; Green et al. 2014; Weiss et al. 2014).

Bacterial cultures were diluted to an $\mathrm{OD}_{600}$ of 0.1. Cellulose acetate membranes (Advantec MFS Inc. $0.2 \mu \mathrm{m}$ pore size) were placed on the surface of an agar plate containing a growth medium. Then, the diluted cultures were plated onto the membranes, and the plates were incubated at $37^{\circ} \mathrm{C}$ for $24 \mathrm{~h}$ (for $48 \mathrm{~h}$ for $M$. avium). Filter papers (Whatman) were soaked in a solution of probe $1(5 \mathrm{mM})$ in $50 \mathrm{mM}$ Tris buffer. The membranes were placed on top of the filter paper soaked in probe 1 solution, and incubated $24 \mathrm{~h}$ at $37^{\circ} \mathrm{C}$.

\section{Results \\ Sulfatase activity tests}

To evaluate the ability of probe $\mathbf{1}$ to detect sulfatase activity, we compared the fluorescence intensities and color changes of probe $\mathbf{1}$ in the presence or absence of commercially available arylsulfatases from Helix pomatia and $A$. aerogenes. We used $1 \mathrm{mM}$ probe 1 and $0.1 \mathrm{mg} /$ $\mathrm{ml}$ of sulfatase from $H$. pomatia, dissolved in $50 \mathrm{mM}$ Tris buffer at $\mathrm{pH}$ 7.4. For about one hour after the initiation of the reaction with the sulfatase, the fluorescence intensity increased in a time-dependent manner $\left(\Phi_{\mathrm{F}}=0.146\right.$; the quantum yield was determined using tryptophan $\left(\Phi_{\mathrm{F}}=0.12\right.$ in water) as a standard) (Brouwer 2011). Then, the intensity decreased and colored precipitates formed spontaneously (Fig. 1; Additional file 1: Figures S1, S2).

\section{Calculation of kinetic parameters and detection limits of probe 1}

For the calculation of the kinetic values, we used $0.02 \mathrm{mg} / \mathrm{ml}$ sulfatase from A. aerogenes in $50 \mathrm{mM}$ Tris buffer (pH 7.48) at $37^{\circ} \mathrm{C}$. As shown in Table 1 and Additional file 1: Figure $\mathrm{S} 3$, the $\mathrm{K}_{\mathrm{m}}$ and $\mathrm{V}_{\max }$ values of sulfatase from $A$. aerogenes were determined using probe 1 to be $187 \pm 13 \mu \mathrm{M}$ and $10.9 \pm 0.2 \mu \mathrm{M} / \mathrm{min}$, respectively. To determine the limit of detection (LOD), $1 \mathrm{mM}$ probe 1 was used in $50 \mathrm{mM}$ Tris buffer at $37^{\circ} \mathrm{C}(\mathrm{pH} 7.48)$. LOD values of probe 1 calculated through fluorescence enhancement were $61 \mathrm{ng} / \mathrm{ml}$ for $H$. Pomatia sulfatase and $35 \mathrm{ng} / \mathrm{ml}$ for $A$. aerogenes sulfatase (Table 1; Additional file 1: Table S1). On the other hand, the LODs for $H$. Pomatia sulfatase and $A$. aerogenes sulfatase determined by UV absorbance changes at $630 \mathrm{~nm}$ after $2 \mathrm{~h}$ incubation were 2.5 and $1.99 \mu \mathrm{g} / \mathrm{ml}$, respectively (Table 1; Additional file 1: Table S1).

\section{Colony-based liquid-phase assays}

Four different strains of bacteria were used for the tests. We chose Klebsiella aerogenes which is a gram-negative bacteria having periplasmic arylsulfatases, and M. avium and M. smegmatis possessing arylsulfatase activity which might be related with infection (Mougous et al. 2002). Staphylococcus aureus lacking sulfatase genes was used as a control (Sardiello et al. 2005). Colony-based liquidphase assays were performed by incubating $1 \mathrm{mM}$ probe 1 with bacterial cultures $\left(\mathrm{OD}_{600}=3.0\right)$ in $50 \mathrm{mM}$ Tris buffer (Adachi et al. 1974, 1975; Beil et al. 1995; Harada 1964; Okamura et al. 1976). The fluorescence intensities of probe 1 incubated with $K$. aerogenes, M. avium 


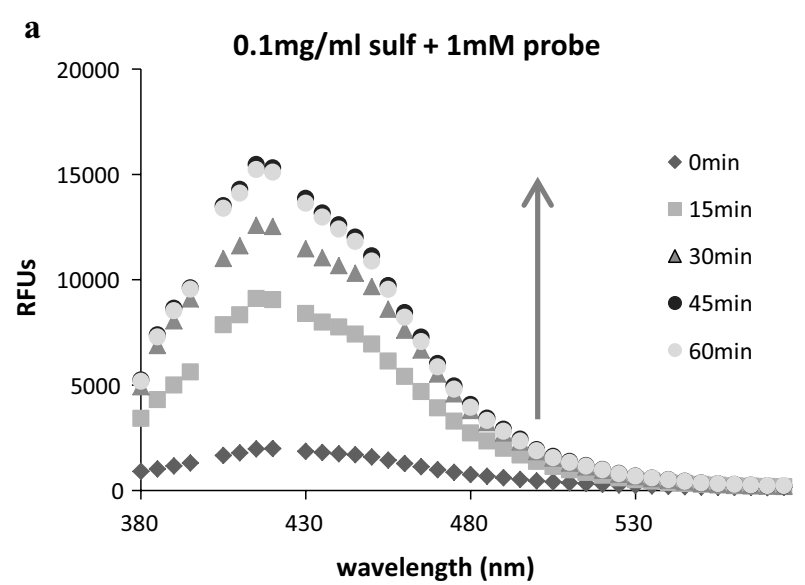

c
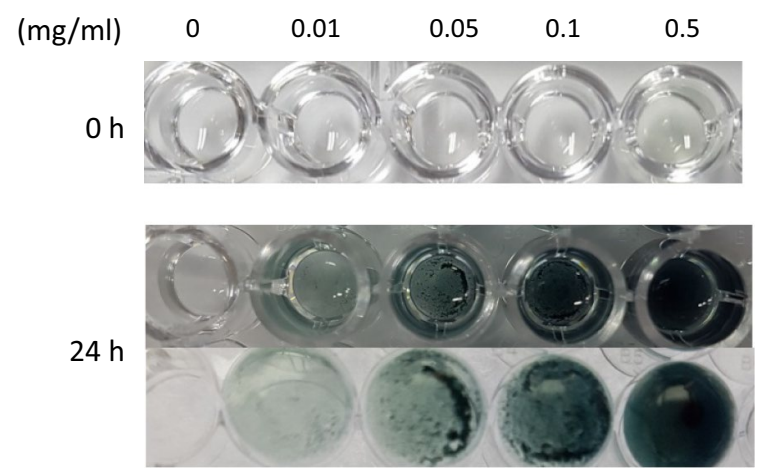

b

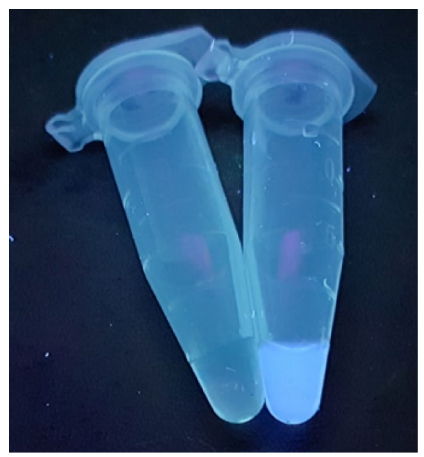

Sulfatase from Aerobacter aerogenes
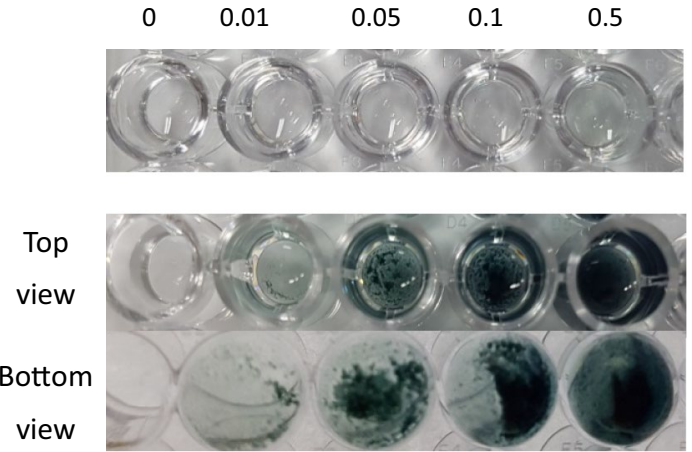

Fig. 1 a Fluorescence intensity enhancement of probe $\mathbf{1}$ upon treatment with sulfatase from Helix pomatia, $\mathbf{b}$ fluorescence emission of probe $\mathbf{1}$ under UV lamp incubated with sulfatase from Helix pomatia for $30 \mathrm{~min}$ and $\mathbf{c}$ generation of colored precipitates after 24-h incubation; 1 mM probe $\mathbf{1}$ with sulfatase from Helix pomatia (left) and from Aerobacter aerogenes (right)

Table 1 Kinetic parameters of $A$. aerogenes sulfatase and detection limits

\begin{tabular}{lllll}
\hline & $\mathrm{K}_{\mathbf{m}}(\boldsymbol{\mu M})$ & $\mathbf{V}_{\max }(\boldsymbol{\mu M} / \mathbf{m i n})$ & LOD $(\mathbf{F I})(\mathbf{n g} / \mathbf{m l})$ & LOD $(\mathbf{U V})(\boldsymbol{\mu g} / \mathbf{m l})$ \\
\hline Probe $\mathbf{1}$ & $187 \pm 13$ & $10.9 \pm 0.2$ & $35.3 \pm 2.6^{\mathrm{b}}$ & $1.99 \pm 0.09^{\mathrm{c}}$ \\
MFS $^{\mathrm{a}}$ & $598 \pm 67$ & $(75 \pm 4.8) \times 10^{-6}$ & $158^{\mathrm{d}}$ & $15.8^{\mathrm{d}}$ \\
RS $^{\mathrm{a}}$ & $162 \pm 10$ & $(606 \pm 12) \times 10^{-6}$ & & $0.0158^{\mathrm{d}}$ \\
-NPS $^{\mathrm{a}}$ & $1800 \pm 120$ & & & \\
\hline
\end{tabular}

a The values were reported in reference, Smith et al. (2014)

b The values were calculated by fluorescence intensity changes at $415 \mathrm{~nm}$ after 30 min incubation

c The values were calculated by UV absorption changes at $630 \mathrm{~nm}$ after $2 \mathrm{~h}$ incubation

$d$ The values were obtained after 10 min incubation

and M. smegmatis colonies and lysates for about an hour increased by 2 - to 3.5-fold (Fig. 2a; Additional file 1: Figure S4), while there were no fluorescence changes of probe 1 incubated with $S$. aureus colonies and lysates that lack sulfatase genes and activity. Moreover, colored precipitates were observed in the lysates of $K$. aerogenes, $M$. avium, and $M$. smegmatis after overnight incubation with probe 1, while probe $\mathbf{1}$ incubated with $K$. aerogenes and $M$. avium colonies generated coloured precipitates after 3 days (Fig. 2b). In case of $M$. smegmatis colonies, the fluorescence intensity was slowly increased but colored precipitates were rarely observed (Fig. 2b; Additional file 1: 


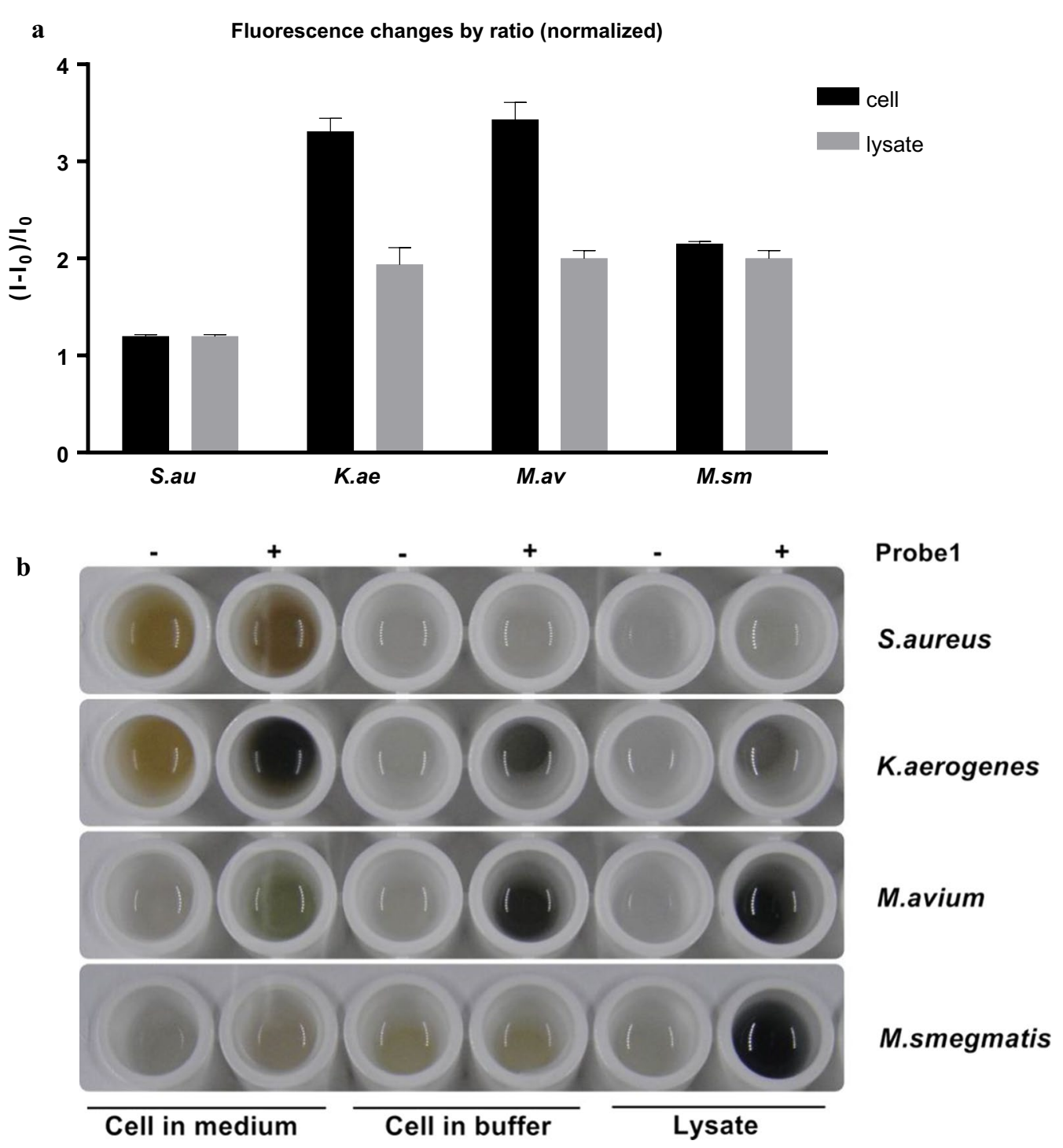

Fig. 2 a Fluorescence enhancement and $\mathbf{b}$ color changes of $1 \mathrm{mM}$ probe $\mathbf{1}$ incubated with S. aureus, K. aerogenes, M. avium and M. smegmatis colonies and lysates

Figure S4). Incubation of probe $\mathbf{1}$ with $S$. aureus colonies and lysates generated no colored precipitates (Fig. 2). To confirm that the changes in the fluorescence signal was solely due to sulfatases, we measured the specific activity of sulfatases by fluorescence changes of probe 1 incubated with different concentrations of proteins of $M$. avium lysates for $30 \mathrm{~min}$. The values of specific activities at $30 \mathrm{~min}$ between different concentrations of the proteins (specific activity of sulfatase $=$ fluorescence intensity/amount of total proteins, see Additional file 1: Figure $\mathrm{S} 4 \mathrm{e}, \mathrm{f}$ for details. Note that Additional file 1: Figure S4e, $\mathrm{f}$ are different sets of experiments) were almost identical, which indicated that the fluorescence enhancement of probe $\mathbf{1}$ was induced by sulfatase in M. avium (Additional file 1: Figure S4).

\section{Solid-phase colony-based assays}

Colonies of $K$. aerogenes on cellulose acetate membrane filters $(0.2 \mu \mathrm{m}$ pore size) were placed on the top of filter papers soaked in $5 \mathrm{mM}$ probe solution and incubated at $37{ }^{\circ} \mathrm{C}$ overnight. As shown in Fig. 3, dark colored colonies were observed on the membrane filter of $K$. aerogenes which was placed on the filter papers soaked in probe solution, whereas only faint colonies were visible on the membrane filter of $K$. aerogenes without probe $\mathbf{1}$. 


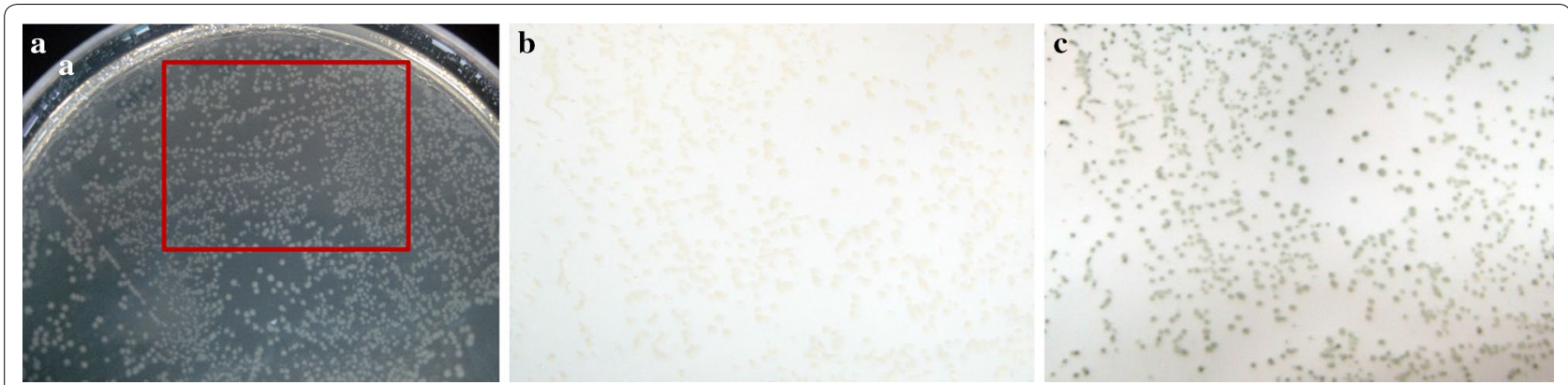

Fig. 3 K. aerogenes a on agar plate, $\mathbf{b}$ on membrane filters without and $\mathbf{c}$ with probe $\mathbf{1}$

\section{Discussion}

We present simple and direct liquid- and solid-phase colony-based assays of bacterial sulfatases using an activitybased probe $\mathbf{1}$. Hydrolysis of probe $\mathbf{1}$ by sulfatases induced fluorescence intensity enhancement and generation of colored precipitates, which enabled monitoring bacterial arylsulfatase activity. The fluorescence enhancement was elicited by the generation of $\mathrm{N}$-methyl isoindole upon treatment with the sulfatase (Yoon and Hong 2017), while precipitation might be caused by post-polymerization of $N$-methyl isoindole molecules (Green et al. 2014).

The fact that probe $\mathbf{1}$ induced the fluorescence enhancement and formation of colored precipitates in a time-dependent manner upon treatment with purified sulfatases (Fig. 1) indicated that probe 1 could be utilized for sulfatase activity assays. As shown in Table 1 and Additional file 1: Table S1, the $\mathrm{K}_{\mathrm{m}}$ value obtained using probe 1 was comparable to those obtained using previously reported fluorogenic sulfatase activity probes, 3-O-methylfluorescein-sulfate (MFS) and resorufine-sulfate (RS) (Smith et al. 2014). Comparing to the $\mathrm{V}_{\max }$ values obtained using MFS and RS which were determined to be $1.25 \pm 0.08 \mathrm{pmol} / \mathrm{s}$ and $10.1 \pm 0.2 \mathrm{pmol} / \mathrm{s}$ (Smith et al. 2014), probe 1 reacted with sulfatase from $A$. aerogenes more rapidly. In addition, considering the incubation time, the LOD values measured by probe $\mathbf{1}$ would be similar to the reported values by fluorogenic probes, MFS (158 ng) and RS (15.8 ng), but the LOD value measured by UV absorbance of probe 1 was larger than that by a chromogenic probe, $p$-NPS (15.8 ng) (Smith et al. 2014). This is presumably due to the post-polymerization of $N$-methyl isoindole, which was generated and accumulated through the hydrolysis of probe $\mathbf{1}$ by sulfatases. In spite of the less sensitivity and longer incubation time for the observation of color changes, probe $\mathbf{1}$ could also provide an easy and simple detection method through naked eye. Therefore, probe $\mathbf{1}$ is a good substrate for bacterial sulfatases and could detect sulfatase activity by fluorometric and colorimetric assays.
We applied probe $\mathbf{1}$ to microorganisms to demonstrate the feasibility to detect arylsulfatase activity in colonybased liquid-phase assays. Fluorescence enhancement of probe 1 with $K$. aerogenes, $M$. avium and $M$. smegmatis (Fig. 2a; Additional file 1: Figure S4) indicated that the bacterial colonies and lysates having sulfatase activity hydrolyzed the sulfate ester of probe $\mathbf{1}$ to generate fluorescent $N$-methyl isoindole. Colored precipitates were also observed except in the well of probe 1 with M. smegmatis colonies (Fig. 2b). This is presumably because the sulfate ester moiety of probe $\mathbf{1}$ was so slowly hydrolyzed by $M$. smegmatis colonies that $N$-methyl isoindole insufficiently generated could not be effectively polymerized (Additional file 1: Figure S4). As a result, it was implied that the sulfate ester of probe $\mathbf{1}$ was cleaved to generate a fluorescent $N$-methyl isoindole by colonies and lysates of $K$. aerogenes, $M$. avium and $M$. smegmatis having sulfatase activity, and colored precipitates were formed by a sufficient amount of $N$-methyl isoindole. In contrast, probe $\mathbf{1}$ did not react with $S$. aureus which lacks sulfatase genes. Therefore, probe $\mathbf{1}$ can be used to detect sulfatase activity of bacteria through fluorescence enhancement and naked eye in liquid-phase colony-based assays.

Finally, we tested the accessibility of probe $\mathbf{1}$ for colony-based solid-phase assays. Solid-phase assays allowed accurate staining, thus enabling the identification of target locations and the selection of target colonies under heterogeneous conditions. The results shown in Fig. 3 indicate that probe $\mathbf{1}$ is suitable for colony-based solidphase assays as its treatment with sulfatase leads to the formation of an insoluble colored product.

In summary, an activity-based probe $\mathbf{1}$ was successfully used for detection of bacterial arylsulfatase activity in liquid- and solid-phase assays. Probe $\mathbf{1}$ was hydrolyzed by bacterial sulfatase, generating $N$-methyl isoindole that leads to fluorescence enhancement and colored precipitates. Although longer incubation time and enough accumulation of $N$-methyl isoindole were required to generate colored precipitates, probe $\mathbf{1}$ is applicable to 
bacterial sulfatase activity assays in liquid- and solidphase through the observation of color changes as well as fluorescence enhancements. Consequently, our probe may offer a simple method for screening and sorting of the potential bacterial colonies having arylsulfatases activity.

\section{Additional file}

Additional file 1. Supplementary information.

\section{Abbreviations}

BSA: bovine serum albumin; OD: optical density; DMSO: dimethyl sulfoxide; LOD: limit of detection.

\section{Authors' contributions}

HYY designed the work, synthesized the probe, performed purified enzyme study and wrote the draft manuscript. HJK performed the bacterial study and SJ guided and participated in the bacterial study. JIH supervised the research and wrote the manuscript. All authors read and approved the final manuscript.

\section{Author details}

'Department of Chemistry, College of Natural Sciences, Seoul National University, Seoul 08826, Republic of Korea. ${ }^{2}$ Antibacterial Resistance Research Laboratory, Department of Discovery Biology, Institute Pasteur Korea, 16 Daewangpangyo-ro 712 beon-gi, Bundang-gu, Seongnam, Gyeonggi-do 13488, Republic of Korea.

\section{Acknowledgements \\ Not applicable.}

\section{Competing interests}

The authors declare that they have no competing interests.

\section{Availability of data and materials}

The datasets supporting the conclusions of this article are included within the article and its additional files.

\section{Ethics approval and consent to participate}

This article does not contain any studies with human participants or animals.

\section{Funding}

This work was supported by the NRF Grant (2015M3A6A4076701,

2014K1A4A7A01074645) funded by the MSIP, Gyeonggi-do, and KISTI.

\section{Publisher's Note}

Springer Nature remains neutral with regard to jurisdictional claims in published maps and institutional affiliations.

Received: 25 May 2017 Accepted: 5 July 2017

Published online: 11 July 2017

\section{References}

Adachi T, Okamura H, Murooka Y, Harada T (1974) Catabolite repression and derepression of arylsulfatase synthesis in Klebsiella aerogenes. J Bacteriol 120(2):880-885

Adachi T, Murooka Y, Harada T (1975) Regulation of arylsulfatase synthesis by sulfur-compounds in Klebsiella aerogenes. J Bacteriol 121(1):29-35

An WF, Tolliday N (2010) Cell-based assays for high-throughput screening. Mol Biotechnol 45(2):180-186

Baud D, Ladkau N, Moody TS, Ward JM, Hailes HC (2015) A rapid, sensitive colorimetric assay for the high-throughput screening of transaminases in liquid or solid-phase. Chem Commun 51(97):17225-17228
Beatty KE, Williams M, Carlson BL, Swarts BM, Warren RM, van Helden PD, Bertozzi CR (2013) Sulfatase-activated fluorophores for rapid discrimination of mycobacterial species and strains. Proc Natl Acad Sci USA 110(32):12911-12916. doi:10.1073/pnas.1222041110

Beil S, Kehrli H, James P, Staudenmann W, Cook AM, Leisinger T, Kertesz MA (1995) Purification and characterization of the arylsulfatase synthesized by Pseudomonas aeruginosa PAO during growth in sulfate-free medium and cloning of the arylsulfatase gene (Atsa). Eur J Biochem 229(2):385-394

Bonnett R, Brown RF, Smith RG (1973) Isoindole. J Chem Soc Perkin Trans 1(13):1432-1436

Bric JM, Bostock RM, Silverstone SE (1991) Rapid insitu assay for indoleaceticacid production by bacteria immobilized on a nitrocellulose membrane. Appl Environ Microb 57(2):535-538

Brouwer AM (2011) Standards for photoluminescence quantum yield measurements in solution (IUPAC Technical Report). Pure Appl Chem 83(12):2213-2228. doi:10.1351/Pac-Rep-10-09-31

Dierks T, Miech C, Hummerjohann J, Schmidt B, Kertesz MA, von Figura K (1998) Posttranslational formation of formylglycine in prokaryotic sulfatases by modification of either cysteine or serine. J Biol Chem 273(40):25560-25564

Dierks T, Schmidt B, Borissenko LV, Peng JH, Preusser A, Mariappan M, von Figura K (2003) Multiple sulfatase deficiency is caused by mutations in the gene encoding the human $\mathrm{C}$-alpha-formylglycine generating enzyme. Cell 113(4):435-444

Diez-Roux G, Ballabio A (2005) Sulfatases and human disease. Annu Rev Genomics Hum Genet 6:355-379. doi:10.1146/annurev. genom.6.080604.162334

Garcia-Sanchez M, Klouza M, Holeckova Z, Tlustos P, Szakova J (2016) Organic and inorganic amendment application on mercury-polluted soils: effects on soil chemical and biochemical properties. Environ Sci Pollut R 23(14):14254-14268

Green AP, Turner NJ, O'Reilly E (2014) Chiral amine synthesis using omegatransaminases: an amine donor that displaces equilibria and enables high-throughput screening. Angew Chem Int Ed 53(40):10714-10717

Hanson SR, Best MD, Wong CH (2004) Sulfatases: structure, mechanism, biological activity, inhibition, and synthetic utility. Angew Chem Int Ed 43(43):5736-5763. doi:10.1002/anie.200300632

Harada T (1964) Formation of sulphatases by Pseudomonas aeruginosa. Biochim Biophys Acta 81(1):193-196

Heal WP, Dang THT, Tate EW (2011) Activity-based probes: discovering new biology and new drug targets. Chem Soc Rev 40(1):246-257

Hickey CA, Kuhn KA, Donermeyer DL, Porter NT, Jin CS, Cameron EA, Jung H, Kaiko GE, Wegorzewska M, Malvin NP, Glowacki RWP, Hansson GC, Allen PM, Martens EC, Stappenbeck TS (2015) Colitogenic Bacteroides thetaiotaomicron antigens access host immune cells in a sulfatase-dependent manner via outer membrane vesicles. Cell Host Microbe 17(5):672-680

Kalyani SS, Sharma J, Singh S, Prem D, Lata (2009) Enrichment and isolation of endosulfan-degrading microorganism from tropical acid soil. J Environ Sci Heal B 44(7):663-672

Kasana RC, Salwan R, Dhar H, Dutt S, Gulati A (2008) A rapid and easy method for the detection of microbial cellulases on agar plates using gram's iodine. Curr Microbiol 57(5):503-507

Kertesz MA (2000) Riding the sulfur cycle-metabolism of sulfonates and sulfate esters in Gram-negative bacteria. FEMS Microbiol Rev 24(2):135-175. doi:10.1016/S0168-6445(99)00033-9

Kim JH, Byun DS, Godber JS, Choi JS, Choi WC, Kim HR (2004) Purification and characterization of arylsulfatase from Sphingomonas sp. AS6330. Appl Microbiol Biotechnol 63(5):553-559

Klose S, Moore JM, Tabatabai MA (1999) Arylsulfatase activity of microbial biomass in soils as affected by cropping systems. Biol Fert Soils 29(1):46-54

Knaust A, Schmidt B, Dierks T, von Bulow R, von Figura K (1998) Residues critical for formylglycine formation and/or catalytic activity of arylsulfatase A. Biochemistry 37(40):13941-13946

Kochi JK, Singleton EA (1968) Autoxidation of N-alkylisoindolines—solvent effects and mechanisms. Tetrahedron 24(13):4649-4665. doi:10.1016/ S0040-4020(01)98662-4

Lim JM, Jang YH, Kim HR, Kim YT, Choi TJ, Kim JK, Nam SW (2004) Overexpression of arylsulfatase in E. coli and its application to desulfatation of agar. J Microbiol Biotechnol 14(4):777-782 
Marquordt C, Fang QH, Will E, Peng JH, von Figura K, Dierks T (2003) Posttranslational modification of serine to formylglycine in bacterial sulfatasesrecognition of the modification motif by the iron-sulfur protein AtsB. J Biol Chem 278(4):2212-2218

Miech C, Dierks T, Selmer T, von Figura K, Schmidt B (1998) Arylsulfatase from Klebsiella pneumoniae carries a formylglycine generated from a serine. J Biol Chem 273(9):4835-4837

Mougous JD, Green RE, Williams SJ, Brenner SE, Bertozzi CR (2002) Sulfotransferases and sulfatases in mycobacteria. Chem Biol 9(7):767-776

Murty VLN, Piotrowski J, Morita M, Slomiany A, Slomiany BL (1992) Inhibition of Helicobacter pylori glycosulfatase activity toward gastric sulfomucin by nitecapone. Biochem Int 26(6):1091-1099

Narkhede CP, Patil AR, Koli S, Suryawanshi R, Wagh ND, Salunke BK, Patil SV (2015) Studies on endosulfan degradation by local isolate Pseudomonas aeruginosa. Biocatal Agric Biote 4(2):259-265. doi:10.1016/j. bcab.2015.01.006

Okamura H, Yamada T, Murooka Y, Harada T (1976) Purification and properties of arylsulfatase of Klebsiella aerogenes identity of enzymes formed by non-repressed and de-repressed synthesis. Agr Biol Chem Tokyo 40(10):2071-2076

Park HJ, Rhee HW, Hong JI (2012) Activity-based fluorescent probes for monitoring sulfatase activity. Bioorg Med Chem Lett 22(15):4939-4941

Rettig W, Wirz J (1976) Electronic-structure and photophysical properties of isoindole and it benzo[F]-derivatives and dibenzo[E, G]-derivatives. Helv Chim Acta 59(4):1054-1074

Rush JS, Beatty KE, Bertozzi CR (2010) Bioluminescent probes of sulfatase activity. ChemBioChem 11(15):2096-2099. doi:10.1002/cbic.201000115
Sardiello M, Annunziata I, Roma G, Ballabio A (2005) Sulfatases and sulfatase modifying factors: an exclusive and promiscuous relationship. Hum Mol Genet 14(21):3203-3217

Smith EL, Bertozzi CR, Beatty KE (2014) An expanded set of fluorogenic sulfatase activity probes. ChemBioChem 15(8):1101-1105. doi:10.1002/ cbic.201400032

Soufi B, Krug K, Harst A, Macek B (2015) Characterization of the E. coli proteome and its modifications during growth and ethanol stress. Front Microbiol 6:103. doi:10.3389/fmicb.2015.00103

Stipanuk MH (1986) Metabolism of sulfur-containing amino-acids. Annu Rev Nutr 6:179-209

Stressler T, Seitl I, Kuhn A, Fischer L (2016) Detection, production, and application of microbial arylsulfatases. Appl Microbiol Biotechnol 100(21):9053-9067

Wang XY, Duan DL, Xu JC, Gao X, Fu XT (2015) Characterization of a novel alkaline arylsulfatase from Marinomonas sp FW-1 and its application in the desulfation of red seaweed agar. J Ind Microbiol Biot 42(10):1353-1362

Weiss MS, Pavlidis IV, Vickers C, Hohne M, Bornscheuer UT (2014) Glycine oxidase based high-throughput solid-phase assay for substrate profiling and directed evolution of (R)- and (S)-selective amine transaminases. Anal Chem 86(23):11847-11853

Yoon HY, Hong JI (2017) Sulfatase activity assay using an activity-based probe by generation of $\mathrm{N}$-methyl isoindole under reducing conditions. Anal Biochem 526:33-38. doi:10.1016/j.ab.2017.03.012

\section{Submit your manuscript to a SpringerOpen ${ }^{\odot}$ journal and benefit from:}

- Convenient online submission

$\checkmark$ Rigorous peer review

- Open access: articles freely available online

- High visibility within the field

- Retaining the copyright to your article

Submit your next manuscript at $>$ springeropen.com 